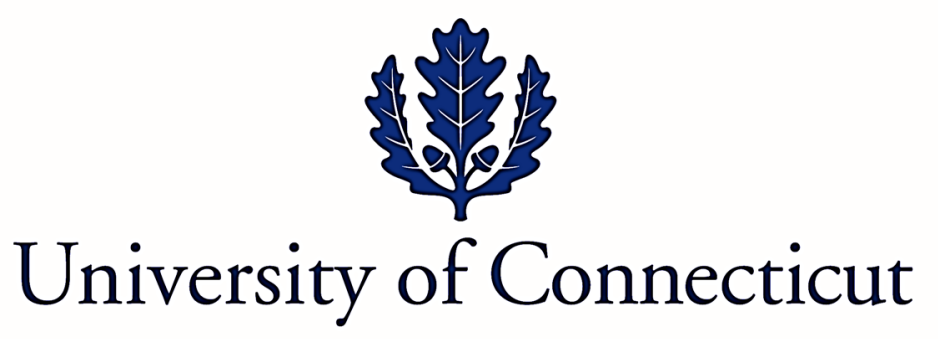

Department of Economics Working Paper Series

The Corporation Is Not a Nexus of Contracts.

It's an iPhone.

by

Richard N. Langlois

University of Connecticut

Working Paper 2016-06

August 2016

365 Fairfield Way, Unit 1063

Storrs, CT 06269-1063

Phone: (860) 486-3022

Fax: (860) 486-4463

http://www.econ.uconn.edu/

This working paper is indexed in RePEc, http://repec.org 


\title{
The Corporation Is Not a Nexus of Contracts. It's an iPhone.
}

\author{
Richard N. Langlois \\ Richard.Langlois@UConn.edu \\ Department of Economics \\ The University of Connecticut \\ Storrs, CT 06269-1063 USA \\ and \\ Institutions and Political Economy Group \\ School of Economic and Business Sciences \\ University of the Witwatersrand \\ Johannesburg, South Africa
}

July 2016

\begin{abstract}
A dominant view in the Coasean law-and-economics tradition is that the firm (including in its form as the corporation) is nothing but a nexus of contracts: the firm is entirely a matter of contract law, and the corporate entity, the legal fiction of corporate personhood, is nothing but a name for a bundle of contracts. This view has implication both for the theory of the firm and for the political economy of the corporation - for the question of the "rights" of corporate entities. By asserting that the corporation is nothing but a set of contractual arrangements, the nexus-of-contracts view implies that any rights possessed by contracting individuals "pass through" to the corporation itself. Unsurprisingly, the powerful phalanx of writers who wish to limit the rights of the corporation take square and largely exclusive aim at the nexus-of-contracts view, assuming that arguments against that view are necessarily arguments against all kinds of "bottom up" accounts of the corporate form. I will argue that critics of the nexus-of-contracts view are indeed right in one sense (though by no means in every sense). Yet, despite this, the fact that the corporation cannot be constructed solely out of voluntary contract narrowly understood does not destroy the argument that the corporation is ultimately "nothing but" a form of cooperation among rights-holding individuals. The corporation understood from the perspective of property rights is both an object of ownership and a form of ownership. Much of the confusion in the literature arises from a procrustean attempt to appraise the corporation in light of simplified and partial accounts of the rights involved.
\end{abstract}

To appear in Francesca Gagliardi and David Gindis, eds., Institutions and Evolution of Capitalism: Essays in Honour of Geoffrey M. Hodgson (Cheltenham: Edward Elgar, 2017). For insightful comments on an earlier draft I am indebted to Richard Adelstein, David Gindis, and Derek Johnson, as well as to participants at the WINIR Symposium on Property Rights, April 4-6, 2016, Bristol, UK. The views and many errors remaining are my own. 
Firms are no less contractual than markets. This was one of the messages of Alchian and Demsetz (1972), a message quickly absorbed by the Coasean tradition of law and economics. A firm differs from a market, they argued, only in that a firm is a contractual system organized around a central agent who is party to the many contracts necessary for team production: contracts with customers, with workers, with suppliers, with investors all flow thorough this central agent. In the original Alchian and Demsetz story, the central agent was a single individual, which limited the reach of their account to the classic ownermanaged firm. Jensen and Meckling quickly extended this idea to the more complex corporate enterprise by making the central agent not a human individual but the corporate entity itself: "most organizations are simply legal fictions which serve as a nexus for a set of contracting relationships among individuals" (Jensen and Meckling 1976, p. 310). "By legal fiction," they explain, "we mean the artificial construct under the law which allows certain organizations to be treated as individuals" (Jensen and Meckling 1976, p. 310n12).

For most within the Coasean law-and-economics tradition, the nexus-of-contracts view implies that the corporation (at least in principle if not always in fact) is entirely a matter of contract law, and the corporate entity, the legal fiction of corporate personhood, is nothing but a name for a bundle of contracts. Easterbrook and Fischel (1985, p. 89) exemplify the nominalist rhetorical stance: "the corporation is not real. It is no more than a name for a complex set of contracts among managers, workers, and contributors of capital. It has no existence independent of these relations."

The nexus-of-contacts view has had significant influence on the theory of the firm, where it was taken to imply that the firm has no clear boundaries, since it is difficult and 
perhaps meaningless to specify which contracts are "inside" and which "outside" the firm. ${ }^{1}$ I want to consider here a related but different issue: the political economy of the corporation or, to put it another way, the question of the "rights" of corporate entities.

Milton Friedman (1970) famously argued that the only responsibility of corporations - he actually talked about the employees of corporations - is to fulfill the wishes of the owners of the corporation, whatever those wishes might be. ${ }^{2}$ Generally but not always, he thought, the owners would want to make as much money as possible, and corporations should accommodate, while adhering to the "basic rules of the society, both those embodied in law and those embodied in ethical custom" (Friedman 1970, p. 33). The rules Friedman had in mind are not responsibilities special to corporations but are those applicable to individuals. A flip side of this position, which has been controversial in the United States (and elsewhere) at least since the early republic, is the assertion that the rights of the owners of the corporation also "pass through" to the corporation. Since the corporation is only the guise in which cooperating individuals act, the corporation is entitled to whatever rights the owners might possess, including (for example) freedom of speech, freedom of religion, and equal protection under the law. Indeed, the corporation

1 Economists like Scott Masten (1988) and Geoffrey Hodgson (2002) have criticized this view, noting in effect that, in creating the corporate entity and in other respects, corporate law provides a clear boundary between what is internal and what external. This argument is related to, but not wholly dependent, on the arguments I consider here.

2 A privately or closely held corporation might want to seek a goal - an eleemosynary goal perhaps, as Friedman suggests - at the expense of profits. But even widely held corporations might want as a matter of enlightened self-interest to seek goals that are not narrowly pecuniary, in a way that doesn't trade off against profits, in order to generate advertising, create goodwill, or influence employee selection and motivation (Birkinshaw et al. 2014). 
itself, in this view, is an example of the free assembly to which Americans have a Constitutional right.

Needless to say, there is an enormous body of thought that disputes these views. What unites opposing positions is that they all must somehow show that the corporation is something else - that it is something other than, or at least more than, just a name for certain modes of voluntary cooperation among rights-holding individuals. Only then would it be possible to assert that corporations have "corporate social responsibilities" different from the responsibilities of individuals. Only then would it be possible to assert that governments may abrogate the rights of corporations - in respect to spending on political speech for example ${ }^{3}$ - in ways and to an extent different from their ability to abrogate the rights of individuals. ${ }^{4}$ Unsurprisingly, in much of this literature the idea of a firm as a nexus of contracts is squarely in the target sights.

I will argue that critics of the nexus of contracts view are right in one sense (though by no means in every sense). Yet, despite this, the fact that the corporation cannot be constructed solely out of voluntary contract narrowly understood does not destroy the argument that the corporation is ultimately "nothing but" a form of cooperation among rights-holding individuals. ${ }^{5}$ Even though the corporation is more than a nexus of contracts, the corporate form does not ipso facto diminish any rights the cooperating individuals may

3 Citizens United v. Federal Election Commission, No. 08-205, 558 U.S. 310 (2010).

4 I am not here claiming, nor do I believe, that the rights of individuals are absolute. A discussion of that issue would take us far afield. The question here is one of equal treatment: whether claims made or actions taken via a corporate entity are evaluated in light of a different set of rights than are the actions or claims of individuals.

5 After I had mostly completed this article, I discovered Mahoney (2000), which takes a similar position, though with different emphasis. 
hold. In order to see why this is so, we need to think less about contracts and more about rights.

\section{Rights in rem.}

Among economists, the best and probably most famous definition of a system of property rights is that of Armen Alchian, for whom such a system is "a method of assigning to particular individuals the 'authority' to select, for specific goods, any use from a nonprohibited class of uses" (Alchian 1965, p. 818). In effect, a right creates a "protected sphere" in which the owner alone has authority over what is possessed.

Along with Demsetz (1967), Alchian was a progenitor not only of the nexus-ofcontracts idea but also of the property-rights school that was another legacy of the work of Coase (1960). Geoffrey Hodgson (2015) has recently criticized this school for its readiness to think of property rights as a matter of possession or de facto control rather than as a right in the abstract or as a right backed up by an institutionalized legal system. Here I have in mind something closer to Hodgson's view: I want to think about property rights in the abstract, about the formal or architectural structure of rights as embodied in a system of what Hayek (1973) calls law as against legislation. Such law, like the common law, may nowadays be enforced by a state-supported apparatus, but is not necessarily created by a state.

Along with legal philosophers like James Penner (1997), the legal theorists Thomas Merrill and Henry Smith (2001a, b) have reasserted a conception of rights that captures the spirit of Alchian's definition. It is also a return to the pre-twentieth-century view of 
property. ${ }^{6}$ Merrill and Smith adopt and clarify the traditional legal distinction between rights in rem and rights in personam. Rights in rem surround a thing - a piece of land or a chattel - and grant the possessor what is essentially dominion: the right to exclude all others from the use of that thing, which is to say, the right to exclude an indefinite number of unspecified others. By contrast, rights in personam involve specific obligations between specific persons. In this view, property follows the logic of in rem; contract follows that of in personam. The argument for the in rem view of property arises out of the information problems of contracting in a complex and changing world (Merrill and Smith 2001a). Ownership in rem creates simple, abstract, and anonymous encapsulation boundaries ${ }^{7}$ (Smith 2011).

The alternative to seeing ownership as a unified, encapsulated authority or dominion is to see ownership as (nothing other than) a "bundle of sticks" that can be added or removed individually. ${ }^{8}$ The sticks are what are sometime called the "incidents" of ownership. In the well-known formulation of A. M. Honoré (1961), there are 11 standard ones, many dating back to Roman conceptions: "They include the right to use a tangible or intangible asset (usus), the right to appropriate the returns from the asset (usus fructus), the right to change a good in substance or location (abusus), the right to the capital derived from the use of the good as collateral, the right to sell a good (alienation), and several other

$6 \quad$ As Blackstone famously put it, property "is that sole and despotic dominion which one man claims and exercises over the external things of the world, in total exclusion of the right of any other individual in the universe" (Blackstone 1775, p. 2).

7 I have argued elsewhere that a system of property rights of this sort is a manifestation of the design principle of modularity (Langlois 2002).

8 As I will imply presently, the problem is not with the idea of transferrable sticks per se but with the way in which the stick-theory is conceptualized. On this see Epstein (2011). 
rights or limitations" (Hodgson 2013, p. 224). Property owners do commonly "contract away" some of their rights, that is, they create in personam relations through contract that then place limits on their own use of the owned object. And it may well be that these contracts often fall into typical categories like those Honoré discusses. But it is wrong to think that these incidents - these contractual possibilities - somehow preexist like arrows in a quiver (Penner 2011). The contractual arrangements come into existence only when the owner creates them, not before; and the owner, understood as someone having authority or dominion, can create often unforeseeable contractual arrangements of indefinite number and type. The owner confers rights; he or she does not transfer them.

There is an important implication for the argument here: in rem rights cannot themselves be created through the mechanism of contract, since contract deals by definition with relations between specific named persons. Property rights thus require law; they are an architectural element of law. But that is not the same thing as saying that they are creatures of the state, even if a state becomes the mechanism for providing the public good of enforcing those rights. In many instances, formal judicial mechanisms come to enforce rights that arose in some spontaneous way: the common law, nowadays enforced ultimately by police forces, is in the main evolved judge-made law (Hayek 1973). As a historical matter, property rights sometimes did emerge as grants from the "state," often meaning feudal warlords or other monopolists in the use of force who could in no circumstances be considered embodiments of a social contract. Over time, however, these granted rights became simpler, more abstract, and less and less connected to the original concession. 
This, broadly speaking, is the history of property law in Western Europe, notably England (Bogart and Richardson 2009). In the feudal legal system, one had a variety of rights over land, as well as a tangle of feudal obligations; but the ultimate owner was the "donor" who granted the land. Steeped in the history and ideas of the English Civil War, English colonists in America were ideologically opposed to anything feudal, and so state constitutions uniformly insisted that all land be titled in free and common socage, which was the simplest of all possible feudal landholdings (Hughes 1977, p. 24-25). Yet even in free and common socage there remained the fiction of a "donor," who was the true owner of the land and to whom was owed a quitrent. In the United States, the donor could no longer be a monarch or feudal lord, so the state government assumed the role, and the quitrent became the property tax. It remains the case that if you don't pay your property tax, the state or locality can seize your property. Yet for all practical purposes property rights in land are no longer concessions but have passed into the law as abstract rights capable of being held ultimately by individuals.

\section{The corporate entity.}

We can distinguish between bottom-up theories of the corporate entity and top-down theories (Orts 2013). The nexus-of-contracts account is one form of bottom-up theory: the corporate entity is constructed by - is nothing other than - the contractual cooperation of individuals. All too often, opponents of the bottom-up theory imply that the nexus-ofcontracts view is the only possible bottom-up theory and that to discredit it is to discredit the entire program of a bottom-up account. My argument is that this is not so. We should see the corporate entity as a right in rem that can be held by individuals; moreover, we should see it as an architectural component of abstract law not as a concession. The 
corporate entity takes the form of, and extends from, the concept of property right - not from its role as a nexus of contracts (although it certainly does also have that role). This, I claim, is also a bottom-up picture of the corporate entity.

Fundamentally, a top-down theory of the corporation is a concession view: the corporation is (nothing but) the creation of the state, and thus any rights the corporation may have emanate from the state and rest on the discretion of the state. In the U. S., the Supreme Court famously articulated this view in the early Dartmouth College case. "A corporation is an artificial being," said the Court, "invisible, intangible, and existing only in contemplation of law. Being the mere creature of law, it possesses only those properties which the charter of its creation confers upon it, either expressly, or as incidental to its very existence." ${ }^{9}$ Quite apart from larger philosophical questions about the legitimacy of the state's power to create corporate entities, as a historical matter, I will suggest, corporations can exist and have existed without government charters, and indeed the practice of chartering has always been importantly a matter of rent-seeking rather than some necessary prerequisite for the existence of the corporation.

Another large body of literature agrees that the corporation is an "artificial being," though one not necessarily created by the state. In its extreme (and rather unsettling) version, articulated by the nineteenth-century German Romantic Otto van Gierke and his followers, the corporation is "no fiction, no symbol [but] a living organism and a real person, with body and members and a will of its own" (quoted in Adelstein (2010, p. 331).)

9 Dartmouth College v. Woodward, 17 U.S. 518, 636 (1819). The Court took a very different view later in the century in Santa Clara County v. Southern Pacific Railroad, 118 U.S. 394 (1886), and the issue remains contested. 
Often inspired by the philosophy of John Searle $(1995,2005)$, more recent scholars have attempted to revive this real-entity idea (Adelstein 2010, 2013; Gindis 2009; Orts 2013). Although denying that the firm is only a nexus of contracts, their approach is far more congenial to a bottom-up view of the corporation. ${ }^{10}$ The neo-real-entity scholars take from Searle the idea of institutional facts: institutions like money - or the firm - do not have any real existence apart from the thoughts and actions of humans, yet they are nonetheless facts in the sense that, and to the extent that, humans behave as if those entities had a real existence. Unlike the concession view, the real-entity approach sees the firm as an entity not because the state decrees it but because it is an institutionalized solution to a transaction-cost problem. Law may codify the rules that underlie the institution, but in the end it is law that serves the institution, not the other way around. In Adelstein's account, the solution to the transaction-cost problems lies not in a nexus of simple contracts but in a complex relational contract, and it requires the development of a set of routines and capabilities that inhere in the team character of the organization. "When we say that a firm 'acts' in a certain way, we mean that specific individuals do specific things in the context of the contract that constitutes their firm that the contractors (and others) agree to describe as actions of the firm" (Adelstein 2010, p. 342).

Perhaps the most compelling argument against the pure nexus-of-contracts view actually comes from within the larger edifice of the Coasean law-and-economics tradition. Hansmann and Kraakman (2000a, b) have pointed out that the corporation cannot be

10 Orts (2013) maintains that this present-day real-entity approach is neither top-down nor bottom up but exists in an "institutional" space between top-down and bottom-up. I would argue that, properly understood, a self-consciously bottom-up account can also be a "institutional." 
strictly a product of contract. Many have long claimed that limited contractual liability is prima facie evidence that the corporation is a concession. This is not so: limited contractual liability, meaning the shielding of the owners' assets from the claims of the corporation's creditors, is merely a feature that creditors can "price in." The insight of Hansmann and Kraakman is that the flip side of limited liability - entity shielding - cannot be cheaply constructed out of contract law. Entity shielding means protecting the assets of the corporate entity itself from the creditors of the owners, thus partitioning the owners' assets into those that are corporate and those that are personal. To accomplish this through contract - contracts with all the owners' current and unknown future creditors - would be a transaction-cost nightmare. Thus entity shielding must emerge from law in much the way property rights more generally emerge from law. The corporate entity is in rem not in personam.

Although constructed out of law rather than out of contract narrowly understood, the asset partitioning of entity shielding injects no involuntary elements into the architecture of the corporation. Potential contractors know ahead of time which set of assets they are dealing with and can adjust accordingly. But this is not so for involuntary creditors - the victims of torts. Limited tort liability is a major source of ammunition for those who oppose the idea that the owners of a corporation express their rights through the corporation: it borders on schizophrenia to claim that owners have rights while absolving them of responsibility for tort victims (Ireland 2016). 
Note first of all that limited tort liability decreases in importance as the size of the corporation increases. ${ }^{11}$ As a historical matter, tort victims welcomed the idea of corporate personhood as the corporation grew in size, since it enabled them to sue with low transaction costs a single well-financed entity instead of a multiplicity of owners, some of whom might be judgment proof (Kahan 2009). Nonetheless, one might indeed view limited tort liability as an asymmetrical - and perhaps unnecessary - attribute of the corporation as a form of ownership. Indeed, those who have most consistently championed the rights of corporate owners have also challenged the legitimacy of limited tort liability. ${ }^{12}$ And, although one might construct a transaction-cost or risk-bearing argument for limiting tort liability, there is also a strain of thought within the Coasean tradition - famously from Hansmann and Kraakman (1991) once again - that sees limited tort liability as both unnecessary and inefficient, at least in a regime of pro rata rather than joint-and-several shareholder liability. In this view, eliminating unlimited tort liability would probably have little effect on the desirability of the corporate form and would at best improve economic efficiency by encouraging more accurate pricing of risky activities. Thus a bottom-up corporate form without schizophrenia could easily exist, and arguably might have existed if, consistent with the historical possibilities to which I now turn, it had emerged out of legal innovation in private law rather than out of (albeit rather minimalist) state chartering.

11 One of the signal cases in this area involved a New York taxicab impresario who split his enterprise into ten distinct companies, all thinly capitalized, in order to shield his personal assets from liability in the (highly likely) event that one of his drivers were to commit a tort. Walkovszky v. Carlton 223 N.E.2d 6 (N.Y. 1966). Courts can choose to "pierce the corporate veil," but not typically because of this kind of deliberate undercapitalization (Macey and Mitts 2014).

12 One need look no further than Murray Rothbard (2009, p. 1144), the doyen on late-twentieth-century anarcho-capitalism. 


\section{Law versus concession.}

Corporate law is necessary for the corporate entity. But there is no reason to view such law as a concession of the state. Indeed, the corporation as an institution arguably predates the state. ${ }^{13}$ Much of the present-day discussion of the corporate entity is colored by the looming presence of state chartering since the early-modern period, a time during which state-capacity was growing and during which states learned to use chartering as a mechanism of rent seeking. If we look instead at earlier times and in the interstices of the early-modern period, we can see that the corporate entity could emerge without concession using legal mechanisms drawn from private law.

As early as 1373 , two grain-milling enterprises on the Garonne had effectively incorporated and displayed most of the attributes of the modern corporate form, including limited liability, asset partitioning, alienable shares, and corporate governance (Le Bris et al. 2015). What made this possible was the existence of a legal system that created and enforced property rights. Under the Carolingian legal system, property rights were generated as grants or fiefs from a lord in return for compensation (military service or, increasingly, simple usufruct). In the $12^{\text {th }}$ century, the Count of Toulouse and the priory of Daurade held the rights to the use of the waters of the Garonne, which they enfeoffed to separate sets of mill investors, who then technically became their vassals. Over time, the payments to the feudal lords diminished with inflation, and feudal obligations became attenuated to the point that the feudal entitlement transformed into ordinary shareholding (Le Bris et al. 2015, p. 14). Limited liability followed from the feudal principle that one

13 So believed von Savigny, as cited in Iwai (1999, p. 602). 
could always abandon a fief. And entity shielding followed from other principles of medieval law, in which perpetual life and asset partitioning were available from ecclesiastical models rather than secular concession. ${ }^{14}$ From these medieval property rights evolved the sophisticated corporations of the fourteenth century.

Another example is England before and during the period of the Bubble Act (17201825). Ron Harris (1994) has argued that the Bubble Act itself - actually initiated before the bursting of the South Sea Bubble - was but one manifestation of a general hostility at the time to incorporation, and access to royal charters or acts of Parliament became extremely costly. As a result, businesses operated without formal incorporation, and there existed in fact a multitude of "unincorporated corporations" that enjoyed most of the benefits of incorporation without a government-granted charter (Anderson and Tollison 1983). These enterprises used existing pieces of the law to cobble together "a preincorporation system that offered many of the effects of separate personality, asset partitioning and limited liability" (Getzler and Macnair 2005, p. 272). The crucial in rem element of these arrangements was the law of trusts: “The organization's real and personal property would be placed in the names of trustees, and trustees selected by the subscribers to the organization would be authorized in certain instances to act in the society's behalf'15 (DuBois 1938, p. 217).

14 This legal system was quite sophisticated. The medieval enfeoffment of the mills used a form of ownership called "pariage" (Le Bris et al. 2015, p. 9).

15 Note that the law of trusts is equity not common law. Common law is in fact extremely conservative when it comes to creating new forms of ownership, and there is debate in the literature about whether this is a good thing (Hansmann and Kraakman 2002; Merrill and Smith 2000). 
In America after the Revolution, state governments inherited the former Crown prerogative of incorporation, which they exercised with enthusiasm (Maier 1993). In contrast to chartering in England (Harris 1994), charters in the U. S. were an important source of state revenue and patronage (Wallis 2005). Both consumers and potential competitors quickly began to chafe at the restrictions of these highly personalized charters, however, and by the early nineteenth century states began offering more general incorporation, though the charters under even these more liberal statutes continued to be larded with restrictions of rent-seeking origin (Lamoreaux 2014). Restricted state-level charters proved especially unsuited to the large multi-unit enterprises that began to arise in the late nineteenth century (Chandler 1977), enterprises that needed not only to raise large amounts of capital but also to operate across state lines. To solve this problem, S. C. T. Dodd, general counsel to the largest of these enterprises - Standard Oil - resurrected the eighteenth-century English solution: a stock-transfer trust (Hovencamp 1991, p. 291). Under this arrangement, a set of trustees, prominently including John D. Rockefeller, would in essence provide the legal persona with which to encapsulate a nexus of interstate contracts.

The trust form might well have developed into a genuine bottom-up structure of corporate personality. ${ }^{16}$ In the event, however, the state of Ohio would not give up its authority easily, and it sued successfully to have the trust declared to have been ex vires outside the powers of the company's original Ohio charter. Standard was forced to recede back to a congeries of state-chartered units. Within a few years, however, the rise of the

16 Possibly without the feature of limited tort liability. 
large inter-state enterprise had begun to change the rent-seeking dynamic, and states suddenly began competing to offer increasingly open and liberal incorporation as a way of attracting revenue (Butler 1985; Grandy 1989). By the turn of the twentieth century, incorporation in New Jersey (later Delaware) became available as a simple method of achieving what Dodd had set out to do. So even though it was state chartermongering, not pure private ordering under the law of trusts, that ended up yielding a relatively unencumbered and anonymous form of corporate personhood in the United States, the ultimate result was arguably more-or-less what it might have been under pure private ordering.

Ultimately, the corporate person is no more - or no less - a concession of the state than is an abstract right to property. States have treated, and in many if not most parts of the world still do treat, the right to property and the right to form perpetually lived organizations as state prerogatives. They do this largely in order to create and redistribute rents. But the emergence of modern open-access orders has been a movement away from concession and rent seeking toward abstract rights in law (North et al. 2009). From both a conceptual and a historical perspective, we can see the corporate entity as an evolved legal doctrine, the result, in effect, of a spontaneous process.

\section{Do corporations have rights?}

What makes the discussion of corporate rights difficult and confusing is that the corporate entity is at once a thing that can be owned and a form of ownership, in the same sense that fee simple is a form of ownership. As Iwai notices, "an incorporated business firm is composed legally of not one but two ownership relations: the shareholders own the 
corporation as a legal thing and the corporation as a legal person own the corporate assets" (Iwai 1999, p. 1999, emphasis original) In some respects, the corporate entity is like a patent, a taxi medallion, or an allotment of pollution or electromagnetic spectrum: it is an incorporeal thing created in law that can be traded. But, quite apart from being - as I have argued - more a creature of law and less of state concession, the corporate entity differs in a crucial way from a patent or a medallion: it is not a use-right stick packaged for trade but rather an object in which inhere full in rem rights of ownership.

One implication is that corporations do not have rights. The corporate entity is a mechanism through which owners exercise their rights. A printing press is an entity with a real existence distinct from those who own or use it. If an unfashionable tract issues from the printing press, we would never say that the press is exercising its right to free speech; we would say that the owner is using the press to exercise his or her right to free speech. The corporate entity is no less a vehicle for its owners to exercise their rights. It doesn't help to say that the corporation is a more complex entity than a printing press. Dan-Cohen (1986) rightly argues that a corporation is essentially an intelligent machine. So maybe the corporation is an iPhone rather than a printing press.

It might be objected here that, unlike a printing press, a corporation as an entity certainly does have rights: it can own assets and write contracts. Adelstein (2013) makes a cogent argument that the firm qua entity should have only those rights it needs to conduct business and should not have any of the moral or political rights of individuals like freedom of speech or freedom of religion. Yet, in addition to being an entity, the corporation is also a kind of property right. And for that reason one might well wonder - controversially, 
perhaps - whether, in addition to possessing a subset of rights as an entity, the firm may also be a conduit for the moral and political rights of its owners, just as ordinary property like a printing press may be such a conduit.

To see why this is so, we must think harder about the meaning of ownership. Rather than own specific assets directly, the owners of the corporation own the entity, which in turn owns all the assets. Moreover, ownership is structured this way even though the large number of owners must delegate day-to-day responsibilities to hired managers. Here is an obvious point of incision for procrustean scholarship. If one can show that the stockholders do not really "own" the corporation, then we needn't worry about the rights of those stockholders passing through the entity they own. Most scholarship does this by focusing on the public-choice problem of diffuse ownership, casting the stockholders as mere creditors (Ireland 1999). Stockholders do not own the company; they own only their shares. They are fundamentally rentiers.

Perhaps surprisingly, economic theory is of some help in understanding why this view is wrong. At least since Frank Knight (1921), organizational economists have recognized that contracting can never be complete. Because of (perhaps radical) uncertainty and information costs, agents cannot foresee all future contingencies and thus cannot write contracts in enough detail to account for all contingencies. As a result, there must be a residual right of control - the right to decide what to do in situations not covered by the contract. So, in effect, there is necessarily more to ownership than a complete package of fully specified contractual sticks. In the present-day formal version of this 
theory, the residual right of control is very much a right in rem: it is the residual right to determine the use of non-human assets (Hart 1988; Hart and Moore 1990).

Incomplete-contracts theorists would insist that the residual right of control cannot be specified in a contract, essentially by definition. Such rights are inalienable, in the sense that selling them is ipso facto a transfer of ownership. Ultimate discretion - which was Alchian's definition, after all - is the only stick that matters. It defines ownership: selling stock is selling ownership. Some, like Demsetz (1998), have argued that, since high transaction costs make it difficult for stockholders to exercise effective control rights, it is the managers who are the ultimate owners. But this confuses the formal or abstract right of control with a de facto scope of action, in much the same way that many economists often compress the formal idea of property itself into possession (Hodgson 2015). It is another brilliant insight of Hansmann (1988) that, despite the seeming powerlessness of stockholders, they do possess, and it is efficient for them to possess, the formal rights of control, since to allocate those rights to managers would exacerbate the stockholdermanager agency problem. Ownership rights do not disappear just because there may be transaction costs of exercising them. ${ }^{17}$

Thus the residual right of control is not merely Honoré's "right to manage." It cuts across many of the incidents: the residual owner may decide, for example, to alter the owned object dramatically or perhaps sell it. (Of course, Honoré's incidents have

Iwai $(1999$, p. 594) argues that, if a single person owns more than 50 per cent of a corporation, the "entity" dissolves and the actions of the corporation are just those of the owner - even, presumably, if there are transaction costs for the single owner in exercising his or her rights through the corporation. But if we take the incomplete-contracts view of ownership, why do not all residual claimants possess rights that may pass through despite the transaction costs involved? 
considerable overlap in general.) The residual right of control implies something closer to the older "dominion" view of ownership. To Hart, the "idea that an owner has residual control rights seems consistent with the standard view of ownership adopted by lawyers" (Hart 1995, p. 30 n. 4). He cites Oliver Wendell Holmes: "But what are the rights of ownership? They are substantially the same as those incident to possession. Within the limits prescribed by policy, the owner is allowed to exercise his natural powers over the subject-matter uninterfered with, and is more or less protected in excluding other people from such interference. The owner is allowed to exclude all, and is accountable to no one" (Holmes 1881, p. 246).

\section{Who Is a Reductionist Now?}

The corporation is a far more complex form of ownership than, say, fee simple, just as an iPhone is a far more complicated device than a single-purpose cellphone. Much of the scholarship on the corporation has been analogous to analyzing the iPhone and finding it objectionable because it has traits that do not fall neatly into the conceptual category of the cellphone. What does it mean to be a cellphone? Can a device have many other features and still be a cellphone? One could wax philosophical. What does it mean to be a legal person? Is the corporation really a legal person if it isn't the same kind of person as an individual ${ }^{18}$

In 1911, Nicholas Murray Butler, the president of Columbia University, declared that "the limited liability corporation is the greatest single discovery of modern times."19

18 On the havoc that's been caused by the misuse of the idea of corporate "personhood," see Gindis (2015).

19 Quoted, among many other places, in Tedlow (1991, p. 25). 
In fact, it had evolved many times in history, an architectural element of law with many fascinating and complex features. But it's still every bit as cool and out-of-the-box as an iPhone. It's about time scholars began treating it that way. 


\section{References.}

Adelstein, Richard. 2010. "Firms as Social Actors," Journal of Institutional Economics 6(3): 329-349.

Adelstein, Richard. 2013. "Firms as Persons," Cahiers d'Économie Politique 65: $161-182$.

Alchian, Armen A. 1965. "Some Economics of Property Rights," Il Politico 30(4): 816-829.

Alchian, Armen and Harold Demsetz. 1972. "Production, Information Costs, and Economic Organization," American Economic Review 62(5): 772795.

Anderson, Gary M. and Robert D. Tollison. 1983. "The Myth of the Corporation as a Creation of the State," International Review of Law and Economics 3(2): 107-120.

Birkinshaw, Julian, Nicolai J. Foss and Siegwart Lindenberg. 2014. "Combining Purpose with Profits," MIT Sloan Management Review 55(3): 49-56 (Spring).

Blackstone, William. 1775. Commentaries on the Laws of England. Book the Second. Oxford: The Clarendon Press, Seventh Edition.

Bogart, Dan and Gary Richardson. 2009. "Making Property Productive: Reorganizing Rights to Real and Equitable Estates in Britain, 16601830," European Review of Economic History 13(1): 3-30 (April).

Butler, Henry N. 1985. "Nineteenth-Century Jurisdictional Competition in the Granting of Corporate Privileges," The Journal of Legal Studies 14(1): $129-166$. 
Chandler, Alfred D., Jr. 1977. The Visible Hand: The Managerial Revolution in American Business. Cambridge: The Belknap Press.

Coase, Ronald H. 1960. "The Problem of Social Cost," Journal of Law and Economics 3: 1-44.

Dan-Cohen, Meir. 1986. Rights, Persons, and Organizations: A Legal Theory for Bureaucratic Society. Berkeley: University of California Press.

Demsetz, Harold. 1967. "Toward a Theory of Property Rights," The American Economic Review 57(2): 347-359.

Demsetz, Harold. 1998. "Oliver Hart, Firms, Contracts, and Financial Structure: Clarendon Lectures in Economics," Journal of Political Economy 106(2): 446-452.

DuBois, Armand B. 1938. The English Business Company after the Bubble Act, 1720-1800. New York: The Commonwealth Fund.

Easterbrook, Frank H. and Daniel R. Fischel. 1985. "Limited Liability and the Corporation," The University of Chicago Law Review 52(1): 89-117.

Epstein, Richard A. 2011. "Bundle-of-Rights Theory as a Bulwark against Statist Conceptions of Private Property," Econ Journal Watch 8(3): 223-235.

Friedman, Milton. 1970. "The Social Responsibility of Business Is to Increase Its Profits," The New York Times Magazine: 32-33 (September 13).

Getzler, Joshua and Mike Macnair. 2005. "The Firm as an Entity before the Companies Act," in Paul Brand, Kevin Costello and W. N. Osborough, 
eds., Adventures of the Law: Proceedings of the Sixteenth British Legal History Conference, 2003. Dublin: Four Courts Press, pp. 267-288.

Gindis, David. 2009. "From Fictions and Aggregates to Real Entities in the Theory of the Firm," Journal of Institutional Economics 5(1): 25-46.

Gindis, David. 2015. "Legal Personhood and the Firm: Avoiding Anthropomorphism and Equivocation," Journal of Institutional Economics FirstView: 1-15.

Grandy, Christopher. 1989. "New Jersey Corporate Chartermongering, 18751929," The Journal of Economic History 49(3): 677-692.

Hansmann, Henry. 1988. "Ownership of the Firm," Journal of Law, Economics and Organization 4(2): 267-304.

Hansmann, Henry and Reinier Kraakman. 1991. "Toward Unlimited Shareholder Liability for Corporate Torts," The Yale Law Journal 100(7): 1879-1934.

Hansmann, Henry and Reinier Kraakman. 2000a. "The Essential Role of Organizational Law," The Yale Law Journal 110(3): 387-440.

Hansmann, Henry and Reinier Kraakman. 2000b. "Organization Law as Asset Partitioning," European Economic Review 44(4-6): 807-817.

Hansmann, Henry and Reinier Kraakman. 2002. "Property, Contract, and Verification: The Numerus Clausus Problem and the Divisibility of Rights," The Journal of Legal Studies 31(S2): S373-S420.

Harris, Ron. 1994. "The Bubble Act: Its Passage and Its Effects on Business Organization," The Journal of Economic History 54(3): 610-627. 
Hart, Oliver. 1995. Firms, Contracts and Financial Structure. Oxford: The Clarendon Press.

Hart, Oliver D. 1988. "Incomplete Contracts and the Theory of the Firm," Journal of Law, Economics and Organization 4(1): 119-139.

Hart, Oliver and John Moore. 1990. "Property Rights and the Nature of the Firm," The Journal of Political Economy 98(6): 1119-1158.

Hayek, F. A. 1973. Law, Legislation, and Liberty. Volume 1: Rules and Order. Chicago: University of Chicago Press.

Hodgson, Geoffrey. 2015. "Much of the 'Economics of Property Rights' Devalues Property and Legal Rights," Journal of Institutional Economics 11(4) (December).

Hodgson, Geoffrey M. 2002. "The Legal Nature of the Firm and the Myth of the Firm-Market Hybrid," International Journal of the Economics of Business 9(1): 37-60.

Hodgson, Geoffrey M. 2013. "Editorial Introduction to 'Ownership' by A. M. Honoré (1961)," Journal of Institutional Economics 9(2): 223-226.

Holmes, Oliver Wendell. 1881. The Common Law. Boston: Little, Brown, and Company.

Honoré, Antony M. 1961. "Ownership," in Anthony G. Guest, ed., Oxford Essays in Jurisprudence. Oxford: Oxford University Press, pp. 107-47.

Hovencamp, Herbert. 1991. Enterprise and American Law, 1836-1937. Cambridge: Harvard University Press. 
Hughes, Jonathan R. T. 1977. The Governmental Habit: Economic Controls from Colonial Times to the Present. New York: Basic Books.

Ireland, Paddy. 1999. "Company Law and the Myth of Shareholder Ownership," The Modern Law Review 62(1): 32-57.

Ireland, Paddy. 2016. "Corporate Schizophrenia: The Corporation as a Separate Legal Person and an Object of Property," paper presented at the WINIR Symposium on Property Rights,, April 4-6, Bristol, UK.

Iwai, Katsuhito. 1999. "Persons, Things and Corporations: The Corporate Personality Controversy and Comparative Corporate Governance," The American Journal of Comparative Law 47(4): 583-632.

Jensen, Michael C. and William H. Meckling. 1976. "Theory of the Firm: Managerial Behavior, Agency Costs and Ownership Structure," Journal of Financial Economics 3(4): 305-360.

Kahan, Daniel R. 2009. "Shareholder Liability for Corporate Torts: A Historical Perspective," The Georgetown Law Journal 97: 1085-1110.

Knight, Frank H. . 1921. Risk, Uncertainty, and Profit. Boston: HoughtonMifflin.

Lamoreaux, Naomi R. 2014. "Revisiting American Exceptionalism: Democracy and the Regulation of Corporate Governance in Nineteenth-Century Pennsylvania," National Bureau of Economic Research Working Paper Series No. 20231.

Langlois, Richard N. 2002. "Modularity in Technology and Organization," Journal of Economic Behavior \& Organization 49(1): 19-37 (Sep). 
Le Bris, David, William N. Goetzmann and Sébastien Pouget. 2015. "The Development of Corporate Governance in Toulouse, 1372-1946," NBER Working Paper 21335.

Macey, Jonathan and Joshua Mitts. 2014. "Finding Order in the Morass: The Three Real Justifications for Piercing the Corporate Veil," Cornell Law Review 100(1): 99-156.

Mahoney, Paul G. 2000. "Contract or Concession? An Essay on the History of Corporarte Law," Georgia Law Review 34: 873-893 (Winter).

Maier, Pauline. 1993. "The Revolutionary Origins of the American Corporation," The William and Mary Quarterly 50(1): 51-84.

Masten, Scott E. 1988. "A Legal Basis for the Firm," Journal of Law, Economics and Organization 4(1): 181-198.

Merrill, Thomas W. and Henry E. Smith. 2000. "Optimal Standardization in the Law of Property: The Numerus Clausus Principle," The Yale Law Journal 110(1): 1-70.

Merrill, Thomas W. and Henry E. Smith. 2001a. "The Property/Contract Interface," Columbia Law Review 101(4): 773-852.

Merrill, Thomas W. and Henry E. Smith. 2001b. "What Happened to Property in Law and Economics?," The Yale Law Journal 111(2): 357-398.

North, Douglass C., John Joseph Wallis and Barry R. Weingast. 2009. Violence and Social Orders: A Conceptual Framework for Interpreting Recorded Human History. New York: Cambridge University Press. 
Orts, Eric W. 2013. Business Persons: A Legal Theory of the Firm. New York: Oxford University Press.

Penner, James. 1997. The Idea of Property in Law. Oxford: The Clarendon Press.

Penner, James. 2011. "Potentiality, Actuality, and 'Stick'-Theory," Econ Journal Watch 8(3): 274-278 (September).

Rothbard, Murray. 2009. Man, Economy, and State. Auburn: Ludwig von Mises Institute.

Searle, John R. 1995. The Construction of Social Reality. New York: The Free Press.

Searle, John R. 2005. "What Is an Institution?," Journal of Institutional Economics 1(1): 1-22.

Smith, Henry E. 2011. "Property Is Not Just a Bundle of Rights," Econ Journal Watch 8(3): 279-291.

Tedlow, Richard S. 1991. The Rise of the American Business Corporation. Philadelphia: Harwood Academic Publishers.

Wallis, John Joseph. 2005. "Constitutions, Corporations, and Corruption: American States and Constitutional Change, 1842 to 1852," The Journal of Economic History 65(1): 211-256. 